IRA-International Journal of Education \& Multidisciplinary Studies ISSN 2455-2526; Vol.05, Issue 03 (2016)

Pg. no. 216-224

Institute of Research Advances

http://research-advances.org/index.php/IJEMS



\title{
Active Role Played by Education to Develop Environmental Ethics among Indian Teenagers
}

\author{
Ashish Mishra \\ Junior Research Fellow, Department of Education, \\ University of Allahabad, India.
}

Type of Review: Peer Reviewed.

DOI: http://dx.doi.org/10.21013/jems.v5.n3.p11

\section{How to cite this paper:}

Mishra, A. (2017). Active Role Played by Education to Develop Environmental Ethics among Indian Teenagers. IRA International Journal of Education and Multidisciplinary Studies (ISSN 2455-2526), 5(3), 216-224. doi:http://dx.doi.org/10.21013/jems.v5.n3.p11

(C) Institute of Research Advances

\section{(cc) EY-NC}

This work is licensed under a Creative Commons Attribution-Non Commercial 4.0 International License subject to proper citation to the publication source of the work.

Disclaimer: The scholarly papers as reviewed and published by the Institute of Research Advances (IRA) are the views and opinions of their respective authors and are not the views or opinions of the IRA. The IRA disclaims of any harm or loss caused due to the published content to any party. 


\begin{abstract}
Education plays a vital role in overall development of a child i.e., cognitive, affective and psychomotor. It acts as a lighting lamp to show the right path to guide the human being in a rational manner. Education makes a person competent enough to judge what is right or what is wrong, as well. At present the problem of environmental degradation is very much in limelight. It is observed that lack of proper knowledge and awareness among the citizen regarding conservation of environment is the prime reason for the environmental degradation. Since, India has an advantage of demographic dividend thus; it will be very useful to educate its youth especially the teenagers/adolescents regarding conservation of environment. The adolescents must be aware of environmental morality that should be taught to them in learning centres. The environmental ethics is the philosophical discipline that considers the moral and ethical relationship of human beings to the environment. In other words: what, if any, moral obligation does man has to the preservation and care of the non-human world? Thus, the present paper focuses on the role of education for developing environmental ethics among adolescents in India. It can be inferred that, education can serve as a potent tool in developing environmental ethics among Indian adolescents because; they are the future of the country and have huge potential to incorporate the ethics in environmental conservation to manage the degrading environment.
\end{abstract}

Key Words: Role of Education, Environmental Ethics, Adolescents.

\title{
INTRODUCTION
}

Education plays a vital role in overall development of a child i.e., cognitive, affective and psychomotor. It acts as a lighting lamp to show the right path to guide the human being in a rational manner. Education makes a person competent enough to judge what is right or what is wrong. At present the problem of environmental degradation is very much in limelight. Last decades of the Twentieth century witnessed a world-wide environmental crisis. In modern time human beings are alienated from nature, the main cause behind this is the development of science and growing of industries and human greed. In the name of development humans are destroying their natural environment. India is not free from that type of problems. It is observed that lack of proper knowledge and awareness among the citizen regarding conservation of environment is the prime reason for the environmental degradation. According to Michael (2008), Science education had an important role in developing understanding of concepts that underpin environmental issues, leading potentially to proenvironmental behaviour. $\mathrm{He}$ also argued that the cognitive and affective domains need to be explicitly integrated in science education that informs environmental education, and a sense of relationship is essential for environmental care and responsibility leading to informed action by the learners. Since, India has an advantage of demographic dividend thus; it will be very useful to educate its youth especially the adolescents regarding conservation of environment. The adolescents must be aware of environmental morality that should be taught to them in learning centres. In a study Raina (2015), found an interactional effect of sex and higher secondary stage on Environmental Awareness, as higher secondary level girls were more aware than boys and high school level students, students of private schools were more environmentally aware than their counter parts in government school students as well as, the awareness level of higher secondary students and girls was higher than high school students and boys of high and higher secondary students.

The environmental ethics is the philosophical discipline that considers the moral and ethical relationship of human beings to the environment. In other words: what, if any, moral obligation does man has to the preservation and care of the non-human world? The word 'environment' may be understood as the "collective term for the conditions in which an organism lives, both biotic and abiotic'. Environmental ethics emerged as a new sub-discipline of Practical Philosophy that deals with the ethical problems surrounding environmental protection and conservation. It aims at providing ethical justification and moral motivation for the cause of global environmental protection. On the one hand, at the level of ideas, environmental ethics challenges the dominant and deep-rooted anthropocentrism of modern mainstream ethics and extends the object of our duty to future 
generations and non-human beings as well and on the other hand at the practical level, environmental ethics criticizes the materialistic, hedonistic and consumerist attitude of modern capitalism, and demands for a healthy and green-lifestyle, that is harmonious with nature. Environmental ethics emphasizes upon the development of a sustainable ecology and society with the help of a reciprocal and holistic attitude, where all comprehensive aspects and parts of nature are preserved, protected and do coexist with harmony. The Environmental issues in India are becoming more serious day by day. Present paper focuses on the role of education for developing environmental ethics among adolescents in India. Environmental awareness is very much important as it was envisaged in the National Policy on Education (1986) that, "There is a paramount need to create a consciousness of the environment. It must permeate all ages and all sections of society, beginning with the child. Environmental consciousness should inform teaching in schools and colleges. This aspect will be integrated in the entire educational process." As it was revealed in a study conducted by Mishra (2006) that environmental education has not yet become successful in secondary school. The problems may be enormously diverse and the magnitude of the problems may be stupendous but there cannot be a single and one stroke solution to the problems. That is why a comprehensive approach is necessary encompassing all areas of our activities.

To create general awareness for environment protection every year we celebrate $5^{\text {th }}$, June as World Environment Day, but it is not sufficient to generate environmental ethics in real sense unless students are taught in a particular manner.

\section{EDUCATION AND ENVIRONMENTAL AWARENESS}

Education can be used as a potent tool to proliferate and imbibe the environmental ethics in the students. The need of the hour is to follow the policy of the government in an effective manner to make students aware of their surroundings. But Muthumanikckam and Sarla (2009) found that the higher secondary students have high environmental ethics and the higher secondary students from the private schools have higher environmental ethics than the students from government schools as well as the higher secondary students residing in rented houses have higher environmental ethics than the students residing in their own houses. This shows lack of uniformity in curriculum of different institutions. This also represents lack of will power of the stakeholders in education to provide knowledge of environmental ethics to their students with uniformity. Joshi (2002) conducted a study on relationship between environmental awareness and process outcomes in science of higher secondary school students in Thrissur District, in which he noticed that there existed significant substantial positive correlation between environmental awareness and process outcomes in science of Higher Secondary School pupils of Thrissur district. Therefore, it is pertinent to solve the problem of imbalanced curriculum regarding education of environmental ethics and students from all the streams and SES must be made well versed with the knowledge of their environment and its proper use and protection. Then only the objective of uniformity in environmental education can be accomplished. Kaise and Lappalainen (2004) examined the environmental awareness of children and adolescent in the Ranomafana region Madagascar. Here 8 to 21 year old students and pupils in 18 schools were used to data collection. The objective of their comparative study was to examine the environmental awareness and knowledge of children and adolescents living under different ecological conditions. The role of education in forming environmental awareness was also considered. The findings were as follows; that children in rural area of Madagascar are aware of environmental issues and can relate them to human activities. The effects of education on environmental concern were significant, but when the effects of degradation could be felt and science in daily life, there is an increase in this awareness. Children's environmental concern and demand for action was stronger in deforested areas. The subjects being studied by the students also influence their knowledge about environmental related issues. Science students exhibit more environmental awareness than Arts or Commerce students (Sharma \& Saraff, 2007). However, Dhar (2007), Upadhyaya \& Kumar (2007) and Singh (2007) had reported that students of Arts and Science stream have equal environmental awareness, environmental attitude and environmental understanding respectively. Raghuvansh (2009) reported equal environmental ethics among students of Arts, Science and Commerce stream. 
On the basis of findings of the study we can conclude that if provided in letter and spirit the environmental education may bring desired awareness among pupils towards their own surroundings irrespective of their SES, Sex, Stream etc.

\section{ROLE PLAYED BY EDUCATION FOR ENVIRONMENTAL ETHICS}

The present section of the paper deals with research evidences that focuses on the role played by education for the development of environmental ethics and awareness among adolescents.

Halder (2012) made an attempt to appraise the status of Environmental Education (E. E.) in higher school education system in India, especially in North Bengal. The source of the data of this empirical study was from field supported by random sampling survey. In the field survey few selective parameters were examined like frequency of environmental class, frequency of practical class regarding environment studies, frequency of field observation class or nature study, type of teaching methodology used, type of evaluation system etc. The status of EE in higher school education system was really not satisfactory and there is a need to standardize and upgrade the education system as a whole.

Uzunboylu et al. (2011) conducted a study on using mobile learning to increase environmental awareness. This study investigated the use of integrating mobile technologies, data services, and multimedia messaging systems to increase students' use of mobile technologies and to develop environmental awareness. Students voluntarily participated in a six-week programme using mobile telephones to transmit photographs of local environmental blights and to exchange pictures and observations and could find that the students' environmental awareness improved positively.

Vellaisamy (2010) conducted a study on environmental achievement in IX standard students through environmental awareness. The study examined junctions and performances of students in strengthening environmental education and environmental awareness. Correlation had been found between the achievements of the students in environmental education and awareness. Environmental education was very important for self-fulfilment and social development. The environmental education was needed for the protection and preservation of environment in order to maintain the quality of life. The outdoor project, the orientation programme was to be given to students to enrich and strengthen the environmental education. Project and out of class activities should also be given to students to increase performance of students.

Muthumanikkan and Sarala (2009) conducted a study about the Environmental Ethics of Higher Secondary School Students. Students of Standard XI, studying in the higher secondary schools in Mayiladuthurai Educational District were taken as the sample for the present study. It was found that the higher secondary students have high environmental ethics. The girls had high environmental ethics than the boys; the higher secondary students from urban areas have higher environmental ethics than: the students from rural areas; the higher secondary students from the private schools had higher environmental ethics than the students from government schools. The higher secondary students residing in rent houses had higher Environmental ethics than the students residing in their own houses. Sharma and

Saraff (2007) have reported that students of CBSE Board are more aware of environment than students of U.P. Board. Kumar (2007) found that students of non-government schools have more environmental understanding than students of government schools. Kaur and Kaur (2009) reported that students of private schools have more environmental awareness than students of government schools.

Sarojini (2009) conducted a study on the Level of Environmental Awareness among the School Students. The study was aimed to find the level of environmental awareness among school students and to find level of environmental awareness among school students. The result of the study indicated that the level of environmental awareness among school students was average. The urban students 
have higher level of awareness than rural students. There was a significant difference in awareness due to the difference in education of parents.

Sijimol and Sudha (2009) conducted a study on the environmental awareness among the secondary school student. This study attempted to investigate the environmental awareness of the secondary school students and the programmes conducted by the school for assessing the environmental awareness. Interview schedules for teachers to collect information about the programmes conducted in schools for improving environmental awareness among the students were used. This study also concluded that there was an improvement in environmental awareness of secondary school students through the environmental education program conducted by the school.

Leege et al. (2008) in their study, on environmental service learning: relevance, rewards and responsibilities, reported that nearly all students participated in the self-learning component of the course and their responses were overwhelmingly positive. This type of learning helped the students, the relevance of content conveyed in the classroom and that they were able to make a difference in their community.

Mazzatenta (2008) conducted a study on the topic "Can global warming heat up environmental education?", which revealed that students who were in direct contact between themselves noted the issue of climate change and how it affected their future lives.

Kumar and Patil (2007) conducted a study on influence of environmental education on environmental attitude of the post graduate students. For this purpose 120 post-graduate students were selected and were administrated the environmental pollution attitude scale. It was found that students with environmental education back ground had better environments attitude. It was also found that there is no significant difference between male and female students in their attitude towards environmental pollution and related issues. Similarly Akkamadevi and Jagadeesh (2009), Kaur and Kaur (2009), Rai and Agnihotri (2008), Dhar (2007) and Eagles and Demare (1999) have reported that male and female students have equal environmental awareness and environmental attitude, environmental consciousness, environmental values (Gupta \& Gautam, 2008). Sharmin (2003) reported no gender difference on performance in environmental issues. However Lee (2009), Maurya (2008) and Dubey (2008) have indicated that female students have more environmental awareness than male students.

Larijani (2007) tried to study about the teachers as ethical architects of environmental education. tracing the need for environmental education in Iran, the author lists certain aspects in society that should be taught to the children, if conservation of nature and living resources, in the context of their importance; is to be achieved. The purpose here is to focus attention on the critical needs of Environmental Education for sustainable development, as they are seen today, and suggest strategies for the future. The result of the study was that all areas of environmental awareness including total scores correlated positively and significantly with total environmental attitude scores and vice versa. From this study it was proved that the teachers with favourable attitude towards environment also had better awareness and other way was also true.

Raju (2007) conducted a study on environmental ethics of Higher Secondary School students of Cuddalore educational district of Tamil Nadu, India. The findings of this study were; the environmental ethics of the Higher Secondary students of Cuddalore educational district is high and girl students have more environmental ethics than the boy students and the rural higher secondary school.

Shivakumar and Mangala (2007) studied the influence of environmental education on environmental attitude of the post graduate students. This was conducted with the aim of studying the level of favourable attitude of the students towards environment in relation to their environmental education. For this purpose, 120 post graduate students were selected and were administered the environmental pollution attitude scale. It was found students with environmental education background had better environmental attitude. 
Shobeiri (2005) conducted a study on secondary school students' environmental awareness in India and Iran. Results indicated that there is significant difference between Indian and Iranian students in their level of environmental awareness. Also there were significant differences between them in environmental awareness across and within two groups with regard to their gender. Also the type of school was a factor which can affect student's environmental awareness in both countries.

Sumitha (2005) conducted a study to prepare an instructional package on environmental studies, to teach environmental studies with the prepared instructional package to students of standard VII and to determine the effectiveness of the instructional package in promoting better understanding of the environment. The instructional package was found effective in prompting a better understanding of the environment. The analysis of the responses of the student through the interview schedule revealed increased sensitivity towards environmental concern and a better understanding of the environment.

Caurin (2001) conducted a study on analysis evaluation and change of attitudes in environment education. The study revealed that it is necessary to impart environmental education combining concepts, procedures and attitudes. Environmental education must be imparted between different subject and course of study in the teaching learning process.

\section{CONCLUSION}

From the thorough analysis of the various studies it is very clear that with the help of proper educational strategy and educational planning we can make our younger generation aware of environmental ethics by one means or the other. Environmental education must be imparted uniformly across all the disciplines and sections of the students without fail. Researches have revealed that environmental education contribute to the development of environmental awareness and favourable attitudes towards the environment (Upadhyaya \& Kumar, 2008; Singh, 2007).

Teaching learning environment must be so created with the help of desired instructional materials as to make students feel the importance of environment in which they live. Teachers may act as the role models for their adolescents thereby channelizing the energies of their students in a proper way to protect environment and surroundings. The highest authorities controlling schools should ensure the fulfilment of prescribed duties assigned to various institutions regarding prescribed course obligation and conduct. In a school the environment of self-learning if created, may develop desired environmental attitude in the adolescents. It will be wise to use Information and Communication Technology (ICT) as the medium of instruction in the field of environmental education to facilitate mass-learning. It will save the time spent and reduce the cost involved in providing education to the targeted learners. Last but not least, there should be provision of proper assessment of knowledge gained by the students in the field of environmental education without which all efforts will be nullified. Therefore, to know, protect and conserve the environment the students must understand environmental ethics and this can be developed very effectively with the help of educating the youth about their environment.

\section{REFERENCES}

1. Akkamahadevi, R. M. \& Jagadeesh, D. H. (2009). Environmental consciousness and behaviour of college students. Shikshamitra, 2 (1), 42-43.

2. Caurin (2001). Retrieved on 19.03.2016 fromhttp://webcache.googleusercontent.com/search?q=cache:http://ir.inflibnet.ac.in:8080/jspui /bitstream/10603/72314/7/chapter\%25202.pdf\&gws_rd=cr\&ei=qfH0Vp3CDMH_ugTig5 SICQ

3. Dhar, S. (2007). Environmental awareness among students at +2 level. Journal of Educational Studies, 5 (1), 19-20.

4. Dubey, R. (2008). A study of environmental awareness and environmental attitude among students. Souvenir of International Conference on Environmental Ethics Education, held on Nov. 16-17, 2008 at Banaras Hindu University. 
5. Eagles, P. F. J. \& Demare, R. (1999). Factors influencing children's environmental attitudes. Journal of Environmental Education, 30.

6. Environmental Ethics \& Human Values: Definition \& Impact on Environmental Problems. Retrieved on 20.03.2016 fromhttp://study.com/academy/lesson/environmental-ethics-human-values-definition-impacton-environmental-problems.html

7. Gupta, R. \& Gautam, P. (2008). Kaksha 8 ke vidyarthiyo ke paryavaran mulyo ka adhyann. Souvenir of International Conference on Environmental Ethics Education, held on Nov. 16-17, 2008 at Banaras Hindu University.

8. Halder, S. (2012). Retrieved on 15.03.2016 fromhttp://webcache.googleusercontent.com/search?q=cache:http://ir.inflibnet.ac.in:8080/jspui /bitstream/10603/72314/7/chapter\%25202.pdf\&gws_rd=cr\&ei=qfH0Vp3CDMH_ugTig5 SICQ

9. Joshi (2002). A study on relationship between environmental Awareness and process outcomes in science of higher secondary school students in Thrissur. Retrieved on 15.03.2016

fromhttp://webcache.googleusercontent.com/search?q=cache:http://ir.inflibnet.ac.in:8080/jspui /bitstream/10603/72314/7/chapter\%25202.pdf\&gws_rd=cr\&ei=qfH0Vp3CDMH_ugTig5 SICQ

10. Kaise \& Lappalainen (2004). Study of the environmental awareness of children and adolescent in the Ranomafana region Madagascar. Retrieved on 26.03.2016 fromhttp://webcache.googleusercontent.com/search?q=cache:http://ir.inflibnet.ac.in:8080/jspui /bitstream/10603/72314/7/chapter\%25202.pdf\&gws_rd=cr\&ei=qfH0Vp3CDMH_ugTig5 SICQ

11. Kaur, R. \& Kaur, M. (2009). Environmental awareness of secondary and senior secondary students. Journal of All India Association for Educational Studies, 21 (1), 8386.

12. Kumar, S. (2007). Parishadiya avam gair parishadiya vidyalayo mai paryavaran bodh ka tulnatmak adhyann. Journal of Educational Studies, 5 (1), 73-74.

13. Kumar, S. K. \& Patil, M. S. (2007). Influence of Environmental Education on Environmental Attitude of the Postgraduate Students, Edutracks, , 6 (8), 34-36.

14. Larijani, M. (2007), Teachers as Ethical Architects of Environmental Education, Edutracks, 7(1),

15. Lee, K. (2009). Gender difference in Hong Kong adolescent consumers' green purchasing behaviour. Journal of Consumer Marketing, 26 (2), 87-96.

16. Leege, L. et al. (2008). Retrieved on 17.03.2016 fromhttp://webcache.googleusercontent.com/search?q=cache:http://ir.inflibnet.ac.in:8080/jspui /bitstream/10603/72314/7/chapter\%25202.pdf\&gws_rd=cr\&ei=qfH0Vp3CDMH_ugTig5 SICQ

17. Maurya, P. (2008). Satvi kaksha ke vidyarthiyo mai paryavaran shiksha ki prabhavshilta ka adhyann. M. Ed. Dissertation, University of Allahabad.

18. Mazzatenta, C. (2008). Retrieved on 18.03.2016 fromhttp://webcache.googleusercontent.com/search?q=cache:http://ir.inflibnet.ac.in:8080/jspui /bitstream/10603/72314/7/chapter\%25202.pdf\&gws_rd=cr\&ei=qfH0Vp3CDMH_ugTig5 SICQ

19. Michael, L. (2008). Science Education for Environmental Awareness: Approaches to Integrating Cognitive and Affective Domains. Retrieved on 15.03.2016 fromhttp://webcache.googleusercontent.com/search?q=cache:http://ir.inflibnet.ac.in:8080/jspui /bitstream/10603/72314/7/chapter\%25202.pdf\&gws_rd=cr\&ei=qfH0Vp3CDMH_ugTig5 SICQ 
20. Mishra, B.B. (2006). Environmental awareness of secondary school students with reference to their intelligence and school background. The Journal of all India Association for Educational Research, 18 (1-2), 71-73.

21. Muthumanikkan \& Sarala (2009). Retrieved on 21.03.2016 fromhttp://webcache.googleusercontent.com/search?q=cache:http://ir.inflibnet.ac.in:8080/jspui /bitstream/10603/72314/7/chapter\%25202.pdf\&gws_rd=cr\&ei=qfH0Vp3CDMH_ugTig5 SICQ

22. National Policy on Education (1986). GoI. Department of Education, MHRD, New Delhi, 1998. Retrieved on 22.03.2016 fromhttp://mhrd.gov.in/sites/upload_files/mhrd/files/document-reports/NPE86-mod92.pdf

23. Raghuvansh, S. (2009). A study of environmental ethics among undergraduate students. Researches and Studies, 61, 18-23.

24. Rai, A. \& Agnihotri, N. (2008). Kanpur sahar ke kaksha 8 mai adhyanrat vidyarthiyo ki paryavaran sambandhi jagrukta ka tulnatmak adhyann. Souvenir of International Conference on Environmental Ethics Education, held on Nov. 16-17, 2008 at Banaras Hindu University.

25. Raina, B. L. (2015). A study of environmental awareness among the higher secondary students in district Kangra, Himachal Pradesh. Asian Resonance. IV (I), 128-133.

26. Raju (2007). A study on environmental ethics of higher secondary school students of Cuddalore educational district of Tamil Nadu, India. Retrieved on 15.03.2016 fromhttp://webcache.googleusercontent.com/search?q=cache:http://ir.inflibnet.ac.in:8080/jspui /bitstream/10603/72314/7/chapter\%25202.pdf\&gws_rd=cr\&ei=qfH0Vp3CDMH_ugTig5 SICQ

27. Sarkar, P. K. (2012). Environmental Ethics and Environmental Issues. International Journal of Multidisciplinary Educational Research, 1 (2), 177-182. Retrived on 20.03.2016 from-http://ijmer.in/pdf/volume1-issue2-2012/177-182.pdf

28. Sarojini (2009). Retrieved on 20.03.2016 fromhttp://webcache.googleusercontent.com/search?q=cache:http://ir.inflibnet.ac.in:8080/jspui /bitstream/10603/72314/7/chapter\%25202.pdf\&gws_rd=cr\&ei=qfH0Vp3CDMH_ugTig5 SICQ

29. Sharma, U. R. \& Sarraff, D. K. (2007). Environmental awareness among students at +2 level. Journal of Educational Studies, 5 (1), 17-18.

30. Sharmin, L. (2003). Assessment of environmental awareness of the students with primary education. Research and Evaluation Division, BRAC, Bangladesh.

31. Shivakumar \& Mangala (2007). The influence of environmental education on environmental attitude of the post graduate students. Retrieved on 22.03.2016 fromhttp://webcache.googleusercontent.com/search?q=cache:http://ir.inflibnet.ac.in:8080/jspui /bitstream/10603/72314/7/chapter\%25202.pdf\&gws_rd=cr\&ei=qfH0Vp3CDMH_ugTig5 SICQ

32. Shobeiri, S.M. (2005). A comparative study of environmental awareness and attitude of teachers and students of secondary schools in India and Iran. Unpublished Ph.D. Thesis, University of Mysore, Mysore. http://webcache.googleusercontent.com/search?q=cache:http://ir.inflibnet.ac.in:8080/jspui /bitstream/10603/72314/7/chapter\%25202.pdf\&gws_rd=cr\&ei=qfH0Vp3CDMH_ugTig5 SICQ

33. Sijimol \& Sudha (2009). Retrieved on 22.03.2016 fromhttp://webcache.googleusercontent.com/search?q=cache:http://ir.inflibnet.ac.in:8080/jspui /bitstream/10603/72314/7/chapter\%25202.pdf\&gws_rd=cr\&ei=qfH0Vp3CDMH_ugTig5 SICQ

34. Singh, B. (2007). Madhyamik vidyalayo ke vibhin vargo ke vidyarthiyo mai paryavaran bodh ka adhyann. Journal of Educational Studies, 5 (1), 66-67. 
35. Sumitha (2005). Retrieved on 22.03.2016 fromhttp://webcache.googleusercontent.com/search?q=cache:http://ir.inflibnet.ac.in:8080/jspui /bitstream/10603/72314/7/chapter\%25202.pdf\&gws_rd=cr\&ei=qfH0Vp3CDMH_ugTig5 SICQ

36. Upadhyaya, P. \& Kumar, A. (2008). Effect of environmental education on environmental awareness and environmental attitude among class VIII students. Souvenir of International Conference on Environmental Ethics Education, held on Nov. 16-17, 2008 at Banaras Hindu University.

37. Upadhyaya, P. Kumar, A. (2007). Environmental attitude among college students. Journal of Educational Studies, 5 (1), 22-24.

38. Uzunboylu, H., Keser, H. et al. (2011). The trends in technology supported collaborative learning studies in 21st century. World Journal on Educational Technology, 3 (2), 103119

39. Vellaisamy (2010). Study of environmental achievement in IX standard students through environmental awareness. Retrieved on 23.03.2016. fromhttp://webcache.googleusercontent.com/search?q=cache:http://ir.inflibnet.ac.in:8080/jspui /bitstream/10603/72314/7/chapter\%25202.pdf\&gws_rd=cr\&ei=qfH0Vp3CDMH_ugTig5 SICQ 